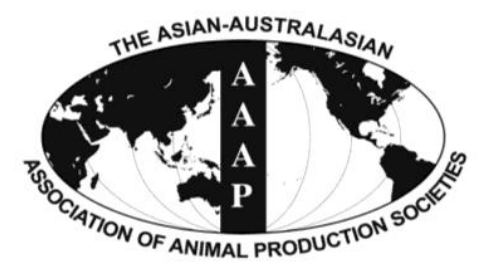

Asian-Aust. J. Anim. Sci.

Vol. 25, No. $3: 341$ - 352

March 2012

www.ajas.info

http://dx.doi.org/10.5713/ajas.2011.11228

\title{
The Main Suppressing Factors of Dry Forage Intake in Large-type Goats
}

\author{
Tran Van Thang, Katsunori Sunagawa*, Itsuki Nagamine, Tetsuya Kishi and Go Ogura \\ Faculty of Agriculture, University of the Ryukyus, 1 Senbaru, Nishihara-cho, Okinawa 903-0213, Japan
}

\begin{abstract}
In large-type goats that were fed on dry forage twice daily, dry forage intake was markedly suppressed after 40 min of feeding had elapsed. The objective of this study was to determine whether or not marked decreases in dry forage intake after 40 min of feeding are mainly caused by the two factors, that is, ruminal distension and increased plasma osmolality induced thirst produced by dry forage feeding. Six large-type male esophageal- and ruminal-fistulated goats (crossbred Japanese Saanen/Nubian, aged 2 to 6 years, weighing $85.1 \pm 4.89 \mathrm{~kg}$ ) were used in two experiments. The animals were fed ad libitum a diet of roughly crushed alfalfa hay cubes for 2 $\mathrm{h}$ from 10:00 to 12:00 am during two experiments. Water was withheld during feeding in both experiments but was available for a period of $30 \mathrm{~min}$ after completion of the $2 \mathrm{~h}$ feeding period. In experiment 1, saliva lost via the esophageal fistula was replenished by an intraruminal infusion of artificial parotid saliva (RIAPS) in sham feeding conditions (SFC) control, and the treatment was maintained under normal feeding conditions (NFC). In experiment 2, a RIAPS and non-insertion of a balloon (RIAPS-NB) control was conducted in the same manner as the SFC control of experiment 1. The intraruminal infusion of hypertonic solution and insertion of a balloon (RIHSIB) treatment was carried out simultaneously to reproduce the effects of changing salt content and ruminal distension due to feed entering the rumen. The results of experiment 1 showed that due to the effects of multiple dry forage suppressing factors when feed boluses entered the rumen, eating rates in the NFC treatment decreased $(p<0.05)$ after 40 min of feeding and cumulative dry forage intake for the $2 \mathrm{~h}$ feeding period reduced to $43.8 \%$ of the SFC control ( $\mathrm{p}<0.01)$. The results of experiment 2 indicated that due to the two suppressing factors of ruminal distension and increased plasma osmolality induced thirst, eating rates in the RIHS-IB treatment were, as observed under NFC, reduced $(\mathrm{p}<0.05)$ and cumulative dry forage intake for the $2 \mathrm{~h}$ feeding period decreased to $34.0 \%$ of the RIAPSNB control $(\mathrm{p}<0.01)$. The combined effects of ruminal distension and increased plasma osmolality accounted for $77.5 \%$ of the suppression of dry forage intake $40 \mathrm{~min}$ after the start of dry forage feeding. The results indicate that ruminal distension and increased plasma osmolality induced thirst are the main factors in the suppression of dry forage intake in large-type goats. (Key Words : Ruminal Distension, Ruminal Fluid Osmolality, Plasma Osmolality, Thirst Level, Dry Forage Intake, Large-type Goats)
\end{abstract}

\section{INTRODUCTION}

In goats fed on dry forage for $2 \mathrm{~h}$ twice daily, eating rates were rapidly decreased in the first 30 or $40 \mathrm{~min}$ of the $2 \mathrm{~h}$ feeding period and remained at low levels during the remaining time (Sunagawa et al., 2002; 2003; 2007). In ruminants under normal feeding conditions whereby feed boluses enter the rumen, ruminal distension, ruminal fluid osmolality, and plasma osmolality induced thirst all increased at the same time during dry forage feeding (Thang et al., 2010). Consequently, it is difficult to clarify which factors are mainly involved in the suppression of dry forage intake after $40 \mathrm{~min}$ of feeding in the experiments conducted under normal feeding conditions (Campling and Balch, 1961; Anil et al., 1993; Grovum, 1995).

\footnotetext{
* Corresponding Author : K. Sunagawa. Tel : +81-98-895-8798, Fax : +81-98-895-8734, E-mail : b986094@agr.u-ryukyu.ac.jp Submitted Jul. 14, 2011; Accepted Oct. 31, 2011; Revised Nov. 6, 2011
}

While there are a number of reports on the factors controlling dry forage intake in ruminants, the majority of them is based on normal feeding conditions and investigates a single factor and its effect on feed intake (Campling and Balch, 1961; Baile and Mayer, 1969; Grovum, 1995). Campling and Balch (1961) reported that feed intake was decreased when a balloon was inserted into the rumen and inflated with water in cows fed on hay and silage. Grovum (1995) reported that when the same dose of hyperosmotic sodium chloride, polyethylene glycol-400 (PEG), sodium acetate or sodium propionate was infused intraruminally to increase ruminal fluid osmolality in sheep, it resulted in the same-sized decrease in alfalfa pellet intake. However, Anil et al. (1993) reported that in cows, if a balloon inserted in the rumen was not filled with enough water or if the increase in ruminal fluid osmolality was insufficient, the amount of dry forage or silage intake was not decreased. From these reports, it remains unclear as to whether or not 
Table 1. A cross-over design in experiment 1

\begin{tabular}{|c|c|c|c|c|}
\hline & First experimental stage & & Second experimental stage & \\
\hline Group A & SFC control & 1 week rest & NFC treatment & 1 week rest \\
\hline Group B & NFC treatment & & SFC control & \\
\hline
\end{tabular}

SFC $=$ Sham feeding conditions $; \mathrm{NFC}=$ Normal feeding conditions

feed intake is depressed by ruminal distension and increases in ruminal fluid osmolality that occur with dry forage feeding under normal feeding conditions.

The utilization of the esophageal-fistulated goats enables the isolation of factors that are presumed to control dry forage intake. Thang et al. $(2010 ; 2011 b)$ has found that in large-type esophageal-fistulated goats were fed dry forage twice daily, the marked decrease in feed intake observed in the second hour of the $2 \mathrm{~h}$ feeding period is related to ruminal distension caused by the feed consumed and the copious amount of saliva secreted during dry forage feeding. In addition, Thang et al. (2011a) also indicated that the marked decreases in dry forage intake after 40 min of feeding are partly caused by increases in plasma osmolality and subsequent thirst sensations produced by dry forage feeding. From these reports, it is thought that the marked decreases in dry forage intake after 40 min of feeding may be caused additively through these multiple factors produced by dry forage feeding. However, the combined effects of ruminal distension and increased plasma osmolality on dry forage intake have not been examined.

The objective of this study was to determine whether or not the marked decreases in dry forage intake after $40 \mathrm{~min}$ of feeding are mainly caused by the two factors, that is, ruminal distension and increased plasma osmolality induced thirst produced by dry forage feeding.

\section{MATERIALS AND METHODS}

\section{Animals}

Six large-type male esophageal- and ruminal-fistulated goats (crossbred Japanese Saanen/Nubian, aged 2 to 6 years, weighing $85.1 \pm 4.89 \mathrm{~kg}$ ) were used in this study. The goats were maintained in individual metabolism cages (length 2 m $\times$ width $1 \mathrm{~m} \times$ height $2 \mathrm{~m}$ ) that allowed for the separate collection of urine and feces. The laboratory room was maintained under thermoneutral conditions (room temperature $22.2 \pm 0.38^{\circ} \mathrm{C}$; relative humidity $83.1 \pm 1.83 \%$ ).

On non-experimental days, the animals were fed twice daily at 10:00 $\mathrm{h}$ and 16:00 $\mathrm{h}$ for $2 \mathrm{~h}$ each time. During the morning feeding period (10:00 to $12: 00 \mathrm{~h}$ ), the animals were fed 1.5 to $2.5 \mathrm{~kg}$ of roughly crushed alfalfa hay cubes. At 16:00 $\mathrm{h}$ each day, the animals were fed $300 \mathrm{~g}$ of hay and $200 \mathrm{~g}$ of concentrated beef cattle feed and half a spoon of multivitamins. The animals were given $5 \mathrm{~L}$ of water at each meal.

\section{Experimental design}

Experiment 1 - The differences between sham and normal feeding conditions : The six esophageal- and ruminal-fistulated goats were divided into two groups (group A: three animals; group B: three animals). The experiment was carried out in accordance with a cross-over design (Table 1). In the first experimental stage, group A was the control and was subjected to the intraruminal infusion of artificial parotid saliva under sham feeding conditions (SFC) while group B as the treatment maintained under normal feeding conditions (NFC). This was reversed in the second experimental stage in which group A was the treatment and maintained under the NFC while group B as the control was subjected to the intraruminal infusion of artificial parotid saliva under the SFC.

In the NFC treatment, the esophageal fistulae were always closed by plugs and the animals ate dry forage in the normal manner. However, in the SFC control, 3.5 L of artificial parotid saliva, a solution resembling parotid saliva (Sunagawa et al., 2008), was intraruminally infused to replenish saliva removed from the esophageal fistula during sham feeding. The intraruminal infusion of artificial parotid saliva was carried out with a bath tub pump and started concurrently with the commencement of feeding. The artificial parotid saliva had an osmolality of 272.1 $\mathrm{mOsmol} / \mathrm{L}, \mathrm{pH} \mathrm{8.6}$, and its concentrations of $\mathrm{Na}^{+}, \mathrm{K}^{+}, \mathrm{Cl}^{-}$, $\mathrm{HCO}_{3}{ }^{-}$, and $\mathrm{HPO}_{4}{ }^{-}$were $142.8 \mathrm{mmol} / \mathrm{L}, 8.8 \mathrm{mmol} / \mathrm{L}, 7.0$ $\mathrm{mmol} / \mathrm{L}, 145 \mathrm{mmol} / \mathrm{L}$, and $40 \mathrm{mmol} / \mathrm{L}$, respectively.

Experiment 2 - The effect of intraruminal infusion of hypertonic solution and insertion of a balloon on dry forage intake during sham feeding : Similar to experiment 1 , the animals were split into two groups (A and B). This experiment was conducted in accordance with a cross-over design (Table 2). In the first experimental stage, group A

Table 2. A cross-over design in experiment 2

\begin{tabular}{|c|c|c|c|c|}
\hline & First experimental stage & & Second experimental stage & \\
\hline Group A & RIAPS-NB control & 1 week rest & RIHS-IB treatment & 1 week rest \\
\hline Group B & RIHS-IB treatment & & RIAPS-NB control & \\
\hline
\end{tabular}

RIAPS-NB = Intraruminal infusion of artificial parotid saliva and non-insertion of a balloon.

RIHS-IB = Intraruminal infusion of hypertonic solution and insertion of a balloon. 
was the control and received the intraruminal infusion of artificial parotid saliva and non-insertion of a balloon (RIAPS-NB) while group B as the treatment was subjected to the intraruminal infusion of hypertonic solution and insertion of a balloon (RIHS-IB). This was reversed in the second experimental stage in which group $\mathrm{A}$ as the treatment was subjected to the RIHS-IB while group B was the control and received the RIAPS-NB.

In the RIAPS-NB control, a balloon was not intraruminally inserted and at the start of feeding, $3.5 \mathrm{~L}$ of artificial parotid saliva was intraruminally infused using a bath tub pump. The artificial parotid saliva with an osmolality, $\mathrm{pH}$, and concentrations of $\mathrm{Na}^{+}, \mathrm{K}^{+}, \mathrm{Cl}^{-}, \mathrm{HCO}_{3}{ }^{-}$, and $\mathrm{HPO}_{4}^{-}$were similar to those in experiment 1 .

In the RIHS-IB treatment, a balloon was intraruminally inserted before the start of feeding and $6.2 \pm 0.38 \mathrm{~L}$ of warm water $\left(35^{\circ} \mathrm{C}\right)$ was infused into the balloon concurrently with the start of feeding using a bath tub pump. The weight of warm water that was infused into the balloon in the rumen in the RIHS-IB treatment was equivalent to the weight of feed boluses removed via an esophageal fistula during the $2 \mathrm{~h}$ feeding period (Thang et al., 2010). The water-filled balloon in the rumen in this experiment was to reproduce the effects of ruminal distension under normal feeding conditions. At the start of feeding, 3.5 L of hypertonic solution was intraruminally infused to reproduce the effects of changing salt content due to feed entering in the rumen under normal feeding conditions using a bath tub pump. The hypertonic solution was made by adding $\mathrm{NaCl}$ into the artificial parotid saliva. The hypertonic solution had an osmolality of 1,240.8 $\pm 124.69 \mathrm{mOsmol} / \mathrm{L}, \mathrm{pH} 8.4 \pm 0.09$, and its concentrations of $\mathrm{Na}^{+}, \mathrm{K}^{+}, \mathrm{Cl}^{-}, \mathrm{HCO}_{3}{ }^{-}$, and $\mathrm{HPO}_{4}{ }^{-}$were $672.3 \pm 55.62 \mathrm{mmol} / \mathrm{L}, \quad 2.8 \pm 0.11 \mathrm{mmol} / \mathrm{L}, \quad 489.4 \pm 15.05$ $\mathrm{mmol} / \mathrm{L}, \quad 36.3 \pm 0.00 \mathrm{mmol} / \mathrm{L}, \quad$ and $\quad 10 \pm 0.00 \mathrm{mmol} / \mathrm{L}$, respectively.

In both experiments, the controls and the treatments were carried out with each group at 1 week intervals to ensure that animals had recovered and to minimize any compounding effect from the previous treatments. In order to ascertain the physiological state of animals, heart rate, respiration rate, and rectal temperature were measured daily prior to the morning feeding period. Heart rate was measured by counting heart sounds with a stethoscope placed $5 \mathrm{~cm}$ behind the left olecranon. Respiration rate was measured by counting respiratory sounds with a stethoscope, and observing and counting thoracic movement that occurs in conjunction with respiration. Rectal temperature was measured using a veterinary thermometer inserted $10 \mathrm{~cm}$ into the rectum for about $10 \mathrm{~min}$.

One day before the start of each treatment, a polyethylene cannula (o.d. $1.50 \mathrm{~mm}$, No. 5, Imamura Gomu, Tokyo, Japan) was inserted into the jugular vein on one side of each goat for collecting blood samples. A three-way tap was attached to the end of each cannula. The cannula was sewn to the skin on the animal's neck and back to secure it and filled with heparin-saline $(50 \mathrm{IU} / \mathrm{ml})$ to prevent coagulation of the blood.

Before starting the SFC control of experiment 1, and both the RIAPS-NB control and the RIHS-IB treatment of experiment 2 in the present study on experimental days, the plug for closing the esophageal fistula was removed and a cannula for collecting boluses was fitted into the fistula. Therefore, all swallowed boluses of dry forage intake and secreted saliva were collected in the cannula through the fistula.

On the experimental days, feeding time started at 10:00 $\mathrm{h}$ and finished at 12:00 $\mathrm{h}$ and during the $2 \mathrm{~h}$ feeding period, animals were fed ad libitum the roughly crushed alfalfa hay cubes. The animals were deprived of water during feeding in the controls and the treatments of both experiments. Following the completion of feeding, water was provided in a bucket and animals were freely drunk water for a period of $30 \mathrm{~min}$ (12:00 to $12: 30 \mathrm{~h})$.

The parameters measured in the present study were rate of eating, cumulative dry forage intake, thirst level, hematocrit, plasma osmolality, plasma concentrations of total protein, glucose, $\mathrm{Na}, \mathrm{K}$, and $\mathrm{Cl}$, ruminal fluid $\mathrm{pH}$, osmolality, and concentrations of $\mathrm{Na}, \mathrm{K}$, and $\mathrm{Cl}$. The rate of eating ( $g$ dry matter (DM)/10 min) and the cumulative dry forage intake (g DM) were measured during the $2 \mathrm{~h}$ of feeding (10:00 to 12:00 h). Eating rate was determined by placing the roughly crushed alfalfa hay cubes in a feed box attached to a scale and measuring the weight of the remaining feed every $10 \mathrm{~min}$ for the duration of the $2 \mathrm{~h}$ feeding period. Fluid intake is regulated by thirst mechanisms (Guyton and Hall, 1996; Prasetiyono et al., 2000). Thirst is a subjective perception that provides the urge for humans and animals to drink fluids (McKinley and Johnson, 2004). The desire to drink, that is, is completely satisfied only when plasma osmolality or blood volume returns to normal. In the present study, thirst level (g/30 min) was defined as water intake for $30 \mathrm{~min}$ upon conclusion of the $2 \mathrm{~h}$ feeding period.

Blood samples (4 ml) were collected at 9:00, 10:00, $10: 15,10: 30,11: 00,11: 30,12: 00$ and 12:30 $\mathrm{h}$ through the polyethylene cannula. Prior to drawing the samples, a drop of heparin solution $(1,000 \mathrm{IU} / \mathrm{ml})$ was placed into a test tube. The blood samples were transferred to these test tubes, which were then placed in ice until plasma separation was carried out by centrifugation $\left(16,260 \times g, 10 \mathrm{~min}, 4^{\circ} \mathrm{C}\right)$.

Ruminal fluid samples $(30 \mathrm{ml})$ were collected at 9:00, $10: 00,10: 15,10: 30,11: 00,11: 30,12: 00$ and 12:30 h through the polyvinyl tube fitted in the ruminal fistula and put into test tubes placed in ice until ruminal fluid 
separation from sediments was carried out by centrifugation $\left(12,320 \times g, 10 \mathrm{~min}, 4^{\circ} \mathrm{C}\right)$.

All surgical and experimental procedures were approved by the Animal Experimental Ethics Committee of the University of the Ryukyus and were in compliance with the Japanese code of practice for the care and use of animals for scientific purposes.

\section{Chemical analysis of feeds}

The alfalfa hay cubes $(84.3 \% \mathrm{DM})$ contained, on a DM basis, $18.7 \%$ crude protein, $2.4 \%$ crude fat, $29.7 \%$ crude fiber, $39.7 \%$ nitrogen-free extract (NFE), $45.9 \%$ neutral detergent fiber (NDF), 36.6\% acid detergent fiber (ADF), $0.10 \% \mathrm{Na}, 2.39 \% \mathrm{~K}, 0.47 \% \mathrm{Cl}, 1.40 \% \mathrm{Ca}, 0.29 \% \mathrm{Mg}$, and $0.23 \% \mathrm{P}$. The proportion of each ingredient in the concentrated beef cattle feed was $48 \%$ maize, $24 \%$ sorghum, $1 \%$ barley, $3.5 \%$ soybean meal, $9.5 \%$ rapeseed meal, $6.0 \%$ wheat bran, $5.0 \%$ rice polishings, $0.5 \%$ molasses, $1.4 \%$ calcium carbonate, $0.5 \%$ alfalfa meal, $0.5 \%$ sodium chloride, $0.05 \%$ dicalcium phosphate, and $0.05 \%$ vitamin trace minerals premix. The concentrated beef cattle feed (86.9\% DM) contained, on a DM basis, $13.4 \%$ crude protein, $3.6 \%$ crude fat, $3.7 \%$ crude fiber, $71.0 \%$ NFE, $14.6 \% \mathrm{NDF}, 5.4 \% \mathrm{ADF}, 0.25 \% \mathrm{Na}, 0.71 \% \mathrm{~K}, 0.31 \% \mathrm{Cl}$, $0.78 \% \mathrm{Ca}, 0.25 \% \mathrm{Mg}$, and $0.48 \% \mathrm{P}$.

Alfalfa hay cubes and concentrated beef cattle feed were subjected to draught drying $\left(70^{\circ} \mathrm{C}, 24 \mathrm{~h}\right)$ and were then ground with a Wiley mill (type 40-525P, Ikemoto, Rika Kougyou, Tokyo, Japan). The diameter of the holes of the mill grid was $1 \mathrm{~mm}$. The chemical components of the feeds were quantified using the procedures described by the AOAC (1990). The chemical component analysis was conducted in triplicate using a total of three samples for each type of feed. The dry matter (DM) content was quantified by oven drying at $135 \pm 2{ }^{\circ} \mathrm{C}$ for $2 \mathrm{~h}$. The crude protein content was calculated from the nitrogen content of the feed determined by a Kjeldhal technique (AOAC, 1990). The crude fat content of feed was determined by continuous extraction with ethyl ether for $16 \mathrm{~h}$ using a Soxhlet extraction apparatus. Crude fiber was determined by subjecting the residue from ether extraction to successive treatments with boiling sulfuric acid $(1.25 \%)$ and sodium hydroxide (1.25\%). Nitrogen-free extract (NFE) was calculated by subtraction of the sum of moisture, ash, crude protein, crude fat and crude fiber content from 100. The ADF and NDF were determined as described Van Soest et al. (1991). For concentrated beef cattle feed, prior to adding the neutral detergent solution, the sample was boiled and pre-treated with $\alpha$-amylase at $40^{\circ} \mathrm{C}$. The samples were charred, ignited and reduced to ash at $550^{\circ} \mathrm{C}$ in an electric furnace. The mineral content of the ash was then measured using an atomic absorption flame emission spectrophotometer (AA-6200, Shimadzu Corporation, Kyoto, Japan). The $\mathrm{Cl}$ content was measured using ion chromatographic methods.

\section{Biochemical analysis}

Blood samples were placed in capillary tubes and centrifuged using a hematocrit centrifuge (HC-12A, Tomy Seiko, Tokyo, Japan; $12,851 \times g, 5 \mathrm{~min}$ ) to determine hematocrit by hematocrit reader (Tomy Seiko, Tokyo, Japan). Plasma total protein concentration and osmolality were measured using a refractometer (Atago, Tokyo, Japan) and an osmometer (OM-6010, Kyoto Daiichi Kagaku, Kyoto, Japan), respectively. Plasma glucose concentration was measured using a Spotchem EZ (SP-4430, Arkray, Tokyo, Japan). The plasma concentrations of $\mathrm{Na}, \mathrm{K}$, and $\mathrm{Cl}$ were measured using a Spotchem EL (SE-1520, Arkray, Kyoto, Japan).

Ruminal fluid was analyzed for osmolality with an osmometer (OM-6010, Kyoto Daiichi Kagaku, Kyoto, Japan), for $\mathrm{pH}$ and $\mathrm{Cl}$ concentration by a $\mathrm{pH} / \mathrm{Ion}$ meter $\mathrm{F}-53$ (Horiba Ltd., Kyoto, Japan), and for concentrations of $\mathrm{Na}$ and $\mathrm{K}$ with an atomic absorption flame emission spectrophotometer (AA-6200, Shimadzu Corporation, Kyoto, Japan).

\section{Statistical analysis}

Factorial analysis (treatment, animal) of variance was performed and subsequent $t$-tests were used to determine the significance of treatment effects. For statistical analysis, General Linear Model (GLM) procedures (SAS Inst., Inc., Cary, NC, 1990) were adopted.

All data were analyzed using the following model:

$$
\mathrm{Y}_{\mathrm{ijklm}}=\mu+\mathrm{G}_{\mathrm{i}}+\mathrm{A}_{\mathrm{ij}}+\mathrm{T}_{\mathrm{k}}+\mathrm{P}_{\mathrm{m}}+\mathrm{E}_{\mathrm{ijklm}}
$$

Where $Y_{i j k l m}=$ the measured variable on the $1^{\text {th }}$ replication of the $\mathrm{j}^{\text {th }}$ animal within the $\mathrm{i}^{\text {th }}$ group, the $\mathrm{k}^{\text {th }}$ treatment and the $\mathrm{m}^{\text {th }}$ period; $\mu=$ the overall mean; $\mathrm{G}_{\mathrm{i}}=$ the effect of the $i^{\text {th }}$ group; $A_{i j}=$ the effect of the $j^{\text {th }}$ animal within the $i^{\text {th }}$ group; $\mathrm{T}_{\mathrm{k}}=$ the effect of the $\mathrm{k}^{\text {th }}$ treatment; $\mathrm{P}_{\mathrm{m}}=$ the effect of the $\mathrm{m}^{\text {th }}$ period; $\mathrm{E}_{\mathrm{ijklm}}=$ the random error effect.

\section{RESULTS}

\section{Experiment 1 - The differences between sham and normal feeding conditions}

Physiological parameters : The mean values of heart rate, respiration rate, and rectal temperature in the SFC control and the NFC treatment were $72.0 \pm 3.10$ and $74.0 \pm 2.53$ beats $/ \mathrm{min}, 16.7 \pm 0.99$ and $17.0 \pm 0.68$ breaths $/ \mathrm{min}$, and $38.1 \pm 0.15$ and $38.3 \pm 0.11^{\circ} \mathrm{C}$, respectively. There were no significant differences between the SFC control and the NFC treatment in the physiological parameters. 
Rate of eating and cumulative dry forage intake : Figure 1 shows rate of eating and cumulative dry forage intake under SFC and NFC. Eating rates in the NFC treatment decreased rapidly in the first $30 \mathrm{~min}$ of feeding ( 0 to $10 \mathrm{~min}$, $497.4 \pm 49.59 \mathrm{~g} ; 20$ to $30 \mathrm{~min}, 174.2 \pm 23.31 \mathrm{~g})$ and subsequently declined gradually to very low rates (ranged from $43.6 \pm 10.31$ to $165.8 \pm 33.56 \mathrm{~g} / 10 \mathrm{~min}$ ) for the remainder of the $2 \mathrm{~h}$ feeding period. Meanwhile, eating rates in the SFC control decreased slowly in the first $30 \mathrm{~min}$ of feeding ( 0 to $10 \mathrm{~min}, 512.8 \pm 41.21 \mathrm{~g} ; 20$ to $30 \mathrm{~min}$, $311.9 \pm 19.22 \mathrm{~g}$ ) and were then remained at high rates during the remaining time of the $2 \mathrm{~h}$ feeding period. Compared with the SFC control, eating rates in the NFC treatment were significantly lower $(\mathrm{p}<0.05)$ from $30 \mathrm{~min}$ after the start of feeding except at 50 and 100 min intervals.

In comparison with the SFC control $(3,332.7 \pm 270.32$ $\mathrm{g} / 2 \mathrm{~h}$ ), cumulative dry forage intake in the NFC treatment $(1,871.5 \pm 109.27 \mathrm{~g} / 2 \mathrm{~h})$ was $43.8 \%$ less $(\mathrm{p}<0.01)$ upon conclusion of the $2 \mathrm{~h}$ feeding period.

Thirst level : Figure 2 shows thirst level under SFC and NFC. In comparison with the SFC control (633.3 \pm 189.15 $\mathrm{g} / 30 \mathrm{~min}$ ), thirst level in the NFC treatment
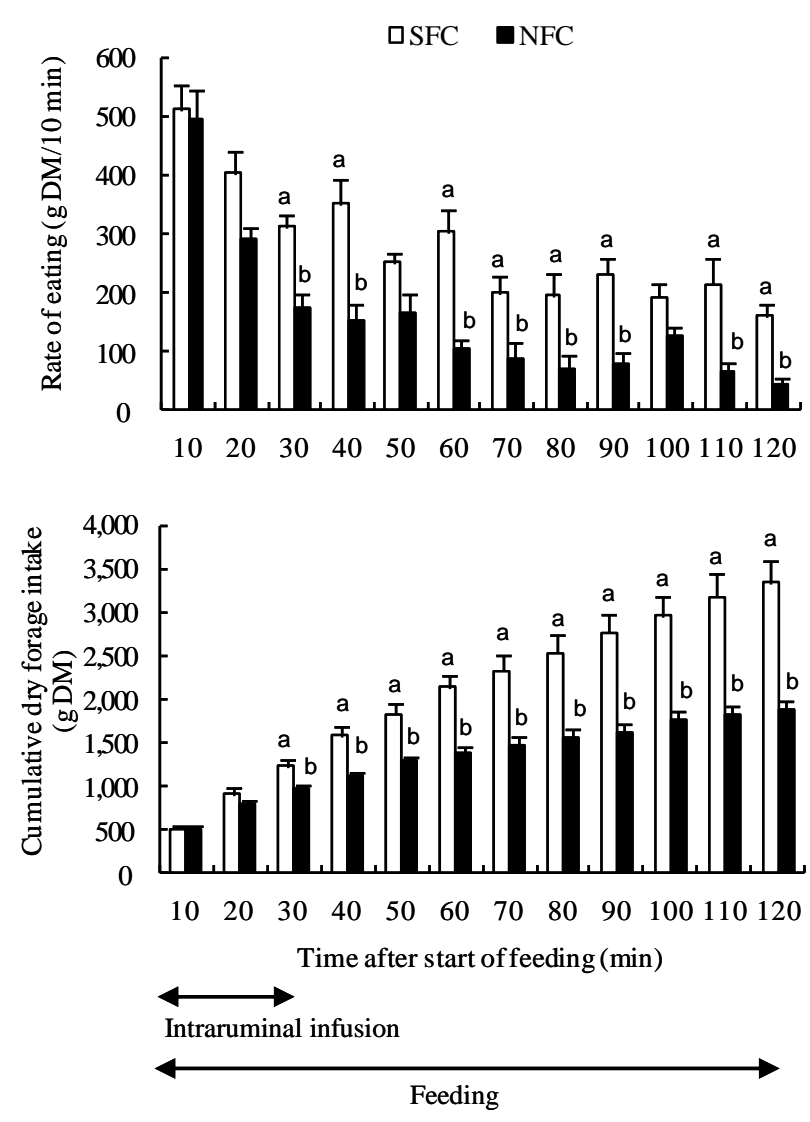

Figure 1. Rate of eating and cumulative dry forage intake under sham feeding conditions (SFC) and normal feeding conditions (NFC). Values are means \pm SE of 6 large-type goats. ${ }^{a, b}$ Means with different superscript are significantly different $(p<0.05)$.

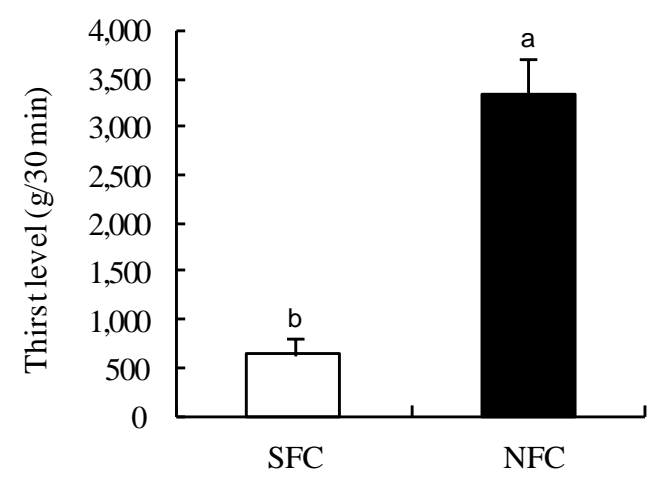

Figure 2. Thirst level under sham feeding conditions (SFC) and normal feeding conditions (NFC). Values are means \pm SE of 6 large-type goats. ${ }^{\mathrm{a}, \mathrm{b}}$ Means with different superscript are significantly different $(\mathrm{p}<0.01)$.

$(3,333.3 \pm 385.28 \mathrm{~g} / 30 \mathrm{~min})$, was $426.3 \%$ greater $(\mathrm{p}<0.01)$ upon conclusion of the 30 min drinking period.

Hematocrit, plasma concentrations of total protein and glucose : Table 3 presents hematocrit, plasma concentrations of total protein and glucose under SFC and NFC. Hematocrit and plasma total protein concentrations in both the SFC control and the NFC treatment increased rapidly during the first $15 \mathrm{~min}$ after the commencement of feeding. Subsequently, hematocrit and plasma total protein concentrations gradually decreased in the NFC treatment while remaining at high level in the SFC control for the remainder of the $2 \mathrm{~h}$ feeding period. Compared with the SFC control, hematocrit and plasma total protein concentrations in the NFC treatment were significantly lower $(\mathrm{p}<0.05)$ at $120 \mathrm{~min}$ and at 30 and $120 \mathrm{~min}$ intervals, respectively.

Plasma glucose concentrations in the SFC control and the NFC treatment were similar. There were no significant differences between the control and the treatment in terms of plasma glucose concentrations during the $2 \mathrm{~h}$ feeding period.

Plasma concentrations of $\mathrm{Na}, \mathrm{K}$ and $\mathrm{Cl}$ : Plasma concentrations of $\mathrm{Na}, \mathrm{K}$ and $\mathrm{Cl}$ under SFC and NFC is shown in Table 3. Plasma concentrations of $\mathrm{Na}$ in the NFC treatment increased gradually while they mostly remained unchanged in the SFC control during the $2 \mathrm{~h}$ feeding period. Compared with the SFC control, plasma concentrations of $\mathrm{Na}$ in the NFC treatment were significantly lower $(\mathrm{p}<0.05)$ at $-60,0$, and $15 \mathrm{~min}$ intervals but they were significantly higher $(\mathrm{p}<0.05)$ at 90, 120, and $150 \mathrm{~min}$ intervals.

Plasma K concentrations in the SFC control and the NFC treatment were similar. There were no significant differences between the control and the treatment in terms of plasma $\mathrm{K}$ concentrations before and during the $2 \mathrm{~h}$ feeding period.

Plasma $\mathrm{Cl}$ concentrations in the SFC control and the 
Table 3. Hematocrit, plasma concentrations of total protein, glucose, $\mathrm{Na}, \mathrm{K}$, and $\mathrm{Cl}$ under sham feeding conditions (SFC) and normal feeding conditions (NFC)

\begin{tabular}{|c|c|c|c|c|c|c|c|c|c|c|c|c|c|c|c|c|c|c|}
\hline \multirow{2}{*}{$\begin{array}{l}\text { Time before } \\
\text { and after start } \\
\text { of feeding } \\
\text { (min) }\end{array}$} & \multicolumn{3}{|c|}{$\begin{array}{l}\text { Hematocrit } \\
(\%)\end{array}$} & \multicolumn{3}{|c|}{$\begin{array}{l}\text { Plasma total protein } \\
\text { (g/dl) }\end{array}$} & \multicolumn{3}{|c|}{$\begin{array}{l}\text { Plasma glucose } \\
\text { (mg/dl) }\end{array}$} & \multicolumn{3}{|c|}{$\begin{array}{c}\text { Plasma Na } \\
(\mathrm{mmol} / \mathrm{L})\end{array}$} & \multicolumn{3}{|c|}{$\begin{array}{l}\text { Plasma K } \\
(\mathrm{mmol} / \mathrm{L})\end{array}$} & \multicolumn{3}{|c|}{$\begin{array}{l}\text { Plasma Cl } \\
(\mathrm{mmol} / \mathrm{L})\end{array}$} \\
\hline & SFC & NFC & $\mathrm{SE}$ & SFC & NFC & SE & SFC & NFC & $\mathrm{SE}$ & SFC & NFC & $\mathrm{SE}$ & SFC & NFC & SE & SFC & NFC & $\mathrm{SE}$ \\
\hline-60 & 25.9 & 26.1 & 1.37 & 7.1 & 7.0 & 0.27 & 66.0 & 67.3 & 2.12 & $140.8^{\mathrm{a}}$ & $138.7^{b}$ & 0.93 & 4.6 & 4.6 & 0.23 & 101.0 & 100.0 & 1.21 \\
\hline 0 & 26.1 & 26.7 & 1.53 & 7.1 & 7.0 & 0.28 & 66.2 & 67.3 & 2.35 & $140.5^{\mathrm{a}}$ & $137.7^{\mathrm{b}}$ & 1.11 & 4.7 & 4.6 & 0.17 & $100.3^{\mathrm{a}}$ & $99.5^{\mathrm{b}}$ & 0.75 \\
\hline 15 & 33.8 & 33.2 & 2.01 & 8.4 & 8.4 & 0.30 & 67.5 & 67.2 & 3.41 & $141.3^{\mathrm{a}}$ & $140.3^{b}$ & 1.27 & 4.8 & 4.7 & 0.15 & 104.8 & 104.2 & 0.96 \\
\hline 30 & 34.3 & 32.3 & 2.23 & $8.6^{\mathrm{a}}$ & $8.1^{b}$ & 0.34 & 66.3 & 66.0 & 2.20 & 140.8 & 141.7 & 1.55 & 4.7 & 4.6 & 0.19 & 105.0 & 105.7 & 1.74 \\
\hline 60 & 34.0 & 32.2 & 2.00 & 8.6 & 8.0 & 0.31 & 65.5 & 67.8 & 3.03 & 141.8 & 142.8 & 1.18 & 4.7 & 4.8 & 0.20 & 105.7 & 105.8 & 1.07 \\
\hline 90 & 34.3 & 32.1 & 2.08 & 8.6 & 8.0 & 0.30 & 68.2 & 67.7 & 4.60 & $140.8^{\mathrm{b}}$ & $143.7^{\mathrm{a}}$ & 1.73 & 4.8 & 4.9 & 0.19 & 105.7 & 106.7 & 1.66 \\
\hline 120 & $34.5^{\mathrm{a}}$ & $30.8^{\mathrm{b}}$ & 2.21 & $8.7^{\mathrm{a}}$ & $7.9^{\mathrm{b}}$ & 0.24 & 65.7 & 70.5 & 3.96 & $142.2^{\mathrm{b}}$ & $146.8^{\mathrm{a}}$ & 1.67 & 4.8 & 4.6 & 0.20 & $105.3^{\mathrm{b}}$ & $108.7^{\mathrm{a}}$ & 1.22 \\
\hline 150 & 29.6 & 29.3 & 1.92 & 7.9 & 7.6 & 0.38 & 68.3 & 70.5 & 3.74 & $140.7^{b}$ & $144.8^{\mathrm{a}}$ & 1.29 & 4.7 & 4.5 & 0.20 & $102.0^{\mathrm{b}}$ & $105.8^{\mathrm{a}}$ & 1.08 \\
\hline
\end{tabular}

Values are means of 6 large-type goats; $\mathrm{SE}=$ Pooled standard error. ${ }^{\mathrm{a}, \mathrm{b}}$ Means in the same row bearing different superscripts differ $(\mathrm{p}<0.05)$.

NFC treatment were similar in the first 90 min of feeding. However, plasma $\mathrm{Cl}$ concentrations in the NFC treatment were significantly higher $(\mathrm{p}<0.05)$ compared with the SFC control at 120 and 150 min intervals.

Osmolality of plasma and ruminal fluid : Figure 3 shows osmolality of plasma and ruminal fluid under SFC and NFC. Plasma osmolality in the NFC treatment increased gradually and reached the level of $314.5 \pm 1.95$
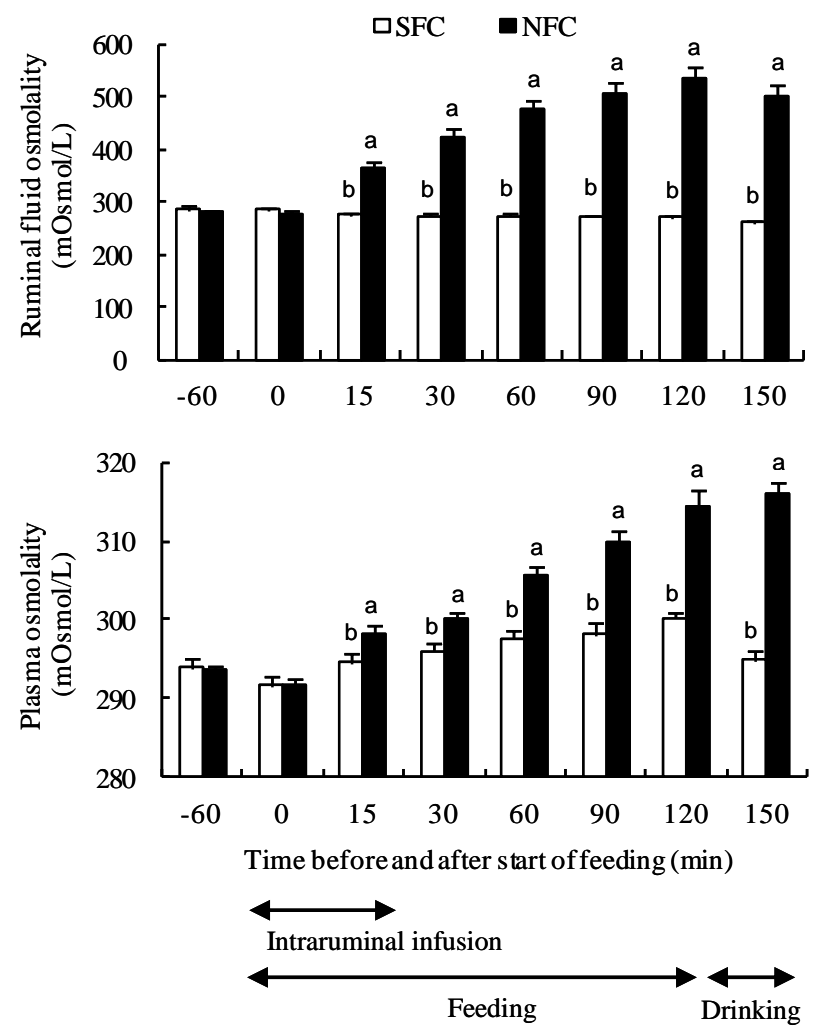

Figure 3. Osmolality of plasma and ruminal fluid under sham feeding conditions (SFC) and normal feeding conditions (NFC). Values are means \pm SE of 6 large-type goats. ${ }^{a, b}$ Means with different superscript are significantly different $(\mathrm{p}<0.05)$.
mOsmol/L upon conclusion of the $2 \mathrm{~h}$ feeding period. Meanwhile, plasma osmolality in the SFC control increased slightly and peaked $(300.2 \pm 0.95 \mathrm{mOsmol} / \mathrm{L})$ upon conclusion of the $2 \mathrm{~h}$ feeding period. Compared with the SFC control, plasma osmolality in the NFC treatment was significantly higher $(\mathrm{p}<0.05)$ from $30 \mathrm{~min}$ after the start of feeding.

Ruminal fluid osmolality in the NFC treatment increased progressively as feeding period elapsed and reached the highest level of $536.8 \pm 19.85 \mathrm{mOsmol} / \mathrm{L}$ upon conclusion of the $2 \mathrm{~h}$ feeding period. Meanwhile, ruminal fluid osmolality in the SFC control mostly remained unchanged during the $2 \mathrm{~h}$ feeding period. Compared with the SFC control, ruminal fluid osmolality in the NFC treatment was significantly higher $(\mathrm{p}<0.01)$ for the duration of the $2 \mathrm{~h}$ feeding period.

Ruminal fluid $\mathrm{pH}$ and concentrations of $\mathrm{Na}, \mathrm{K}$ and $\mathrm{Cl}$ : Table 4 presents ruminal fluid $\mathrm{pH}$ and concentrations of $\mathrm{Na}$, $\mathrm{K}$ and $\mathrm{Cl}$ under SFC and NFC. Ruminal fluid $\mathrm{pH}$ in the SFC control was slightly higher than compared with pre-feeding levels during the $2 \mathrm{~h}$ feeding period. Meanwhile, ruminal fluid $\mathrm{pH}$ in the NFC treatment decreased gradually and reached the lowest level of $6.0 \pm 0.05$ at $150 \mathrm{~min}$ interval. Compared with the SFC control, ruminal fluid $\mathrm{pH}$ in the NFC treatment was significantly lower $(\mathrm{p}<0.01)$ for the duration of the $2 \mathrm{~h}$ feeding period.

In comparison with the SFC control, ruminal fluid concentrations of $\mathrm{Na}$ in the NFC treatment were not significantly different over the $2 \mathrm{~h}$ feeding period. Ruminal fluid concentrations of $\mathrm{K}$ in the SFC control tended to be reduced gradually while they increased progressively in the NFC treatment as feeding period elapsed. Compared with the SFC control, ruminal fluid concentrations of $\mathrm{K}$ in the NFC treatment were significantly higher $(p<0.05)$ over the $2 \mathrm{~h}$ feeding period.

Ruminal fluid concentrations of $\mathrm{Cl}$ in the NFC treatment increased gradually and reached the highest level 
Table 4. Ruminal fluid $\mathrm{pH}$ and concentrations of $\mathrm{Na}, \mathrm{K}$, and $\mathrm{Cl}$ under sham feeding conditions (SFC) and normal feeding conditions (NFC)

\begin{tabular}{|c|c|c|c|c|c|c|c|c|c|c|c|c|}
\hline \multirow{2}{*}{$\begin{array}{l}\text { Time before and } \\
\text { after start of } \\
\text { feeding (min) }\end{array}$} & \multicolumn{3}{|c|}{ Ruminal fluid $\mathrm{pH}$} & \multicolumn{3}{|c|}{$\begin{array}{l}\text { Ruminal fluid } \mathrm{Na} \\
\qquad(\mathrm{mmol} / \mathrm{L})\end{array}$} & \multicolumn{3}{|c|}{$\begin{array}{l}\text { Ruminal fluid } \mathrm{K} \\
\qquad(\mathrm{mmol} / \mathrm{L})\end{array}$} & \multicolumn{3}{|c|}{$\begin{array}{l}\text { Ruminal fluid } \mathrm{Cl} \\
\text { (mmol/L) }\end{array}$} \\
\hline & SFC & NFC & SE & SFC & NFC & SE & SFC & NFC & SE & SFC & NFC & SE \\
\hline-60 & 6.94 & 6.89 & 0.12 & 130.7 & 132.0 & 13.19 & $56.3^{\mathrm{b}}$ & $68.3^{\mathrm{a}}$ & 11.83 & 43.4 & 46.3 & 3.96 \\
\hline 0 & 6.96 & 6.93 & 0.12 & 130.9 & 129.6 & 13.67 & 54.3 & 62.5 & 11.66 & 44.7 & 48.2 & 4.84 \\
\hline 15 & $7.20^{\mathrm{a}}$ & $6.56^{\mathrm{b}}$ & 0.12 & 131.7 & 137.8 & 10.03 & $50.3^{\mathrm{b}}$ & $91.2^{\mathrm{a}}$ & 15.75 & $40.6^{\mathrm{b}}$ & $60.0^{\mathrm{a}}$ & 5.12 \\
\hline 30 & $7.25^{\mathrm{a}}$ & $6.42^{\mathrm{b}}$ & 0.12 & 131.3 & 134.4 & 11.10 & $47.6^{\mathrm{b}}$ & $104.8^{\mathrm{a}}$ & 11.81 & $39.6^{\mathrm{b}}$ & $73.9^{\mathrm{a}}$ & 7.03 \\
\hline 60 & $7.25^{\mathrm{a}}$ & $6.26^{\mathrm{b}}$ & 0.12 & 129.6 & 134.8 & 12.34 & $48.7^{\mathrm{b}}$ & $115.9^{\mathrm{a}}$ & 13.66 & $39.6^{\mathrm{b}}$ & $81.1^{\mathrm{a}}$ & 6.09 \\
\hline 90 & $7.25^{\mathrm{a}}$ & $6.18^{\mathrm{b}}$ & 0.12 & 132.4 & 133.0 & 12.62 & $41.7^{\mathrm{b}}$ & $117.8^{\mathrm{a}}$ & 15.31 & $40.6^{\mathrm{b}}$ & $85.4^{\mathrm{a}}$ & 6.07 \\
\hline 120 & $7.25^{\mathrm{a}}$ & $6.10^{\mathrm{b}}$ & 0.11 & 129.8 & 133.9 & 11.02 & $43.5^{\mathrm{b}}$ & $122.3^{\mathrm{a}}$ & 16.19 & $40.6^{\mathrm{b}}$ & $88.6^{\mathrm{a}}$ & 6.32 \\
\hline 150 & $7.26^{\mathrm{a}}$ & $6.00^{\mathrm{b}}$ & 0.11 & 123.9 & 124.7 & 13.23 & $40.3^{\mathrm{b}}$ & $112.1^{\mathrm{a}}$ & 13.74 & $39.6^{b}$ & $78.0^{\mathrm{a}}$ & 5.12 \\
\hline
\end{tabular}

Values are means of 6 large-type goats; $\mathrm{SE}=$ Pooled standard error. ${ }^{\mathrm{a}, \mathrm{b}}$ Means in the same row bearing different superscripts differ $(\mathrm{p}<0.05$ ).

upon conclusion of the $2 \mathrm{~h}$ feeding period while they mostly remained unchanged in the SFC control for the duration of the $2 \mathrm{~h}$ feeding period. Compared with the SFC control, ruminal fluid concentrations of $\mathrm{Cl}$ in the NFC treatment were significantly higher $(\mathrm{p}<0.05)$ over the $2 \mathrm{~h}$ feeding period.

Experiment 2 - The effect of intraruminal infusion of hypertonic solution and insertion of a balloon on dry forage intake during sham feeding

Physiological parameters : The mean values of heart rate, respiration rate, and rectal temperature in the RIAPSNB control and the RIHS-IB treatment were 72.0 \pm 3.10 and $75.0 \pm 5.08$ beats/min, $16.7 \pm 0.99$ and $16.3 \pm 0.33$ breaths $/ \mathrm{min}$, and $38.1 \pm 0.15$ and $38.3 \pm 0.11^{\circ} \mathrm{C}$, respectively. There were no significant differences between the RIAPS-NB control and the RIHS-IB treatment in the physiological parameters.

Rate of eating and cumulative dry forage intake : Figure 4 shows the effect of RIHS-IB treatment on rate of eating and cumulative dry forage intake. Eating rates in the RIAPS-NB control decreased slowly in the first $30 \mathrm{~min}$ of feeding ( 0 to $10 \mathrm{~min}, 512.8 \pm 41.21 \mathrm{~g} ; 20$ to $30 \mathrm{~min}$, $311.9 \pm 19.22 \mathrm{~g}$ ) and were then remained at high rates during the remaining time of the $2 \mathrm{~h}$ feeding period. Meanwhile, eating rates in the RIHS-IB treatment decreased rapidly in the first $30 \mathrm{~min}$ of feeding ( 0 to $10 \mathrm{~min}, 519.9 \pm 48.75 \mathrm{~g} ; 20$ to $30 \mathrm{~min}, 198.1 \pm 42.75 \mathrm{~g}$ ) and subsequently declined gradually to very low rates (ranged from 95.5 \pm 30.99 to $168.6 \pm 47.49 \mathrm{~g} / 10 \mathrm{~min}$ ) for the rest of the $2 \mathrm{~h}$ feeding period. Compared with the RIAPS-NB control, eating rates in the RIHS-IB treatment were significantly lower $(\mathrm{p}<0.05)$ from 20 to 90 min after the start of feeding.

In comparison with the RIAPS-NB control $(3,332.7 \pm 270.32 \mathrm{~g} / 2 \mathrm{~h})$, cumulative dry forage intake in the RIHS-IB treatment $(2,200.2 \pm 235.15 \mathrm{~g} / 2 \mathrm{~h})$ was $34.0 \%$ less $(\mathrm{p}<0.01)$ upon conclusion of the $2 \mathrm{~h}$ feeding period.
Thirst level : Figure 5 shows the effect of RIHS-IB treatment on thirst level. In comparison with the RIAPS-NB control $(633.3 \pm 189.15 \mathrm{~g} / 30 \mathrm{~min})$, thirst level in the RIHS-IB treatment $(3,525.0 \pm 446.05 \mathrm{~g} / 30 \mathrm{~min})$ was $456.6 \%$ greater $(\mathrm{p}<0.01)$ upon conclusion of the 30 min drinking period.
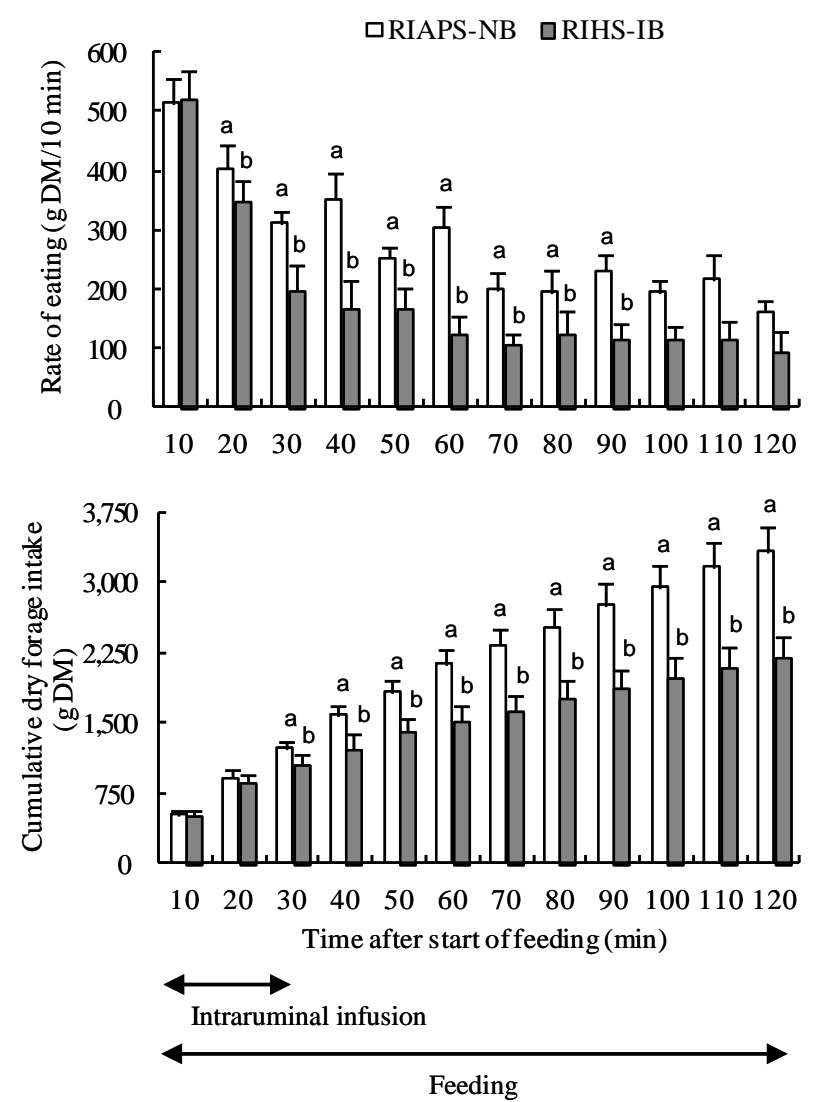

Figure 4. The effect of intraruminal infusion of hypertonic solution and insertion of a balloon (RIHS-IB) on rate of eating and cumulative dry forage intake. Values are means \pm SE of 6 largetype goats. ${ }^{\mathrm{a}, \mathrm{b}}$ Means with different superscript are significantly different $(p<0.05)$ from the intraruminal infusion of artificial parotid saliva and non-insertion of a balloon (RIAPS-NB). 


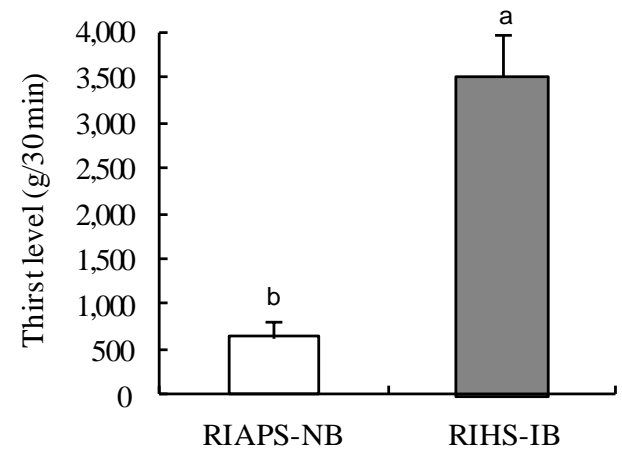

Figure 5. The effect of intraruminal infusion of hypertonic solution and insertion of a balloon (RIHS-IB) on thirst level. Values are means \pm SE of 6 large-type goats. ${ }^{a, b}$ Means with different superscript are significantly different $(p<0.01)$ from the intraruminal infusion of artificial parotid saliva and non-insertion of a balloon (RIAPS-NB).

Hematocrit, plasma concentrations of total protein and glucose : Table 5 presents the effect of RIHS-IB treatment on hematocrit, plasma concentrations of total protein and glucose. Hematocrit and plasma total protein concentrations in both the RIAPS-NB control and the RIHS-IB treatment increased rapidly in the first 15 min after the start of feeding. Subsequently, hematocrit and plasma total protein concentrations decreased gradually in the RIHS-IB treatment while remaining at high level in the RIAPS-NB control for the remainder of the $2 \mathrm{~h}$ feeding period. Compared with the RIAPS-NB control, hematocrit and plasma total protein concentrations in the RIHS-IB treatment were significantly lower $(\mathrm{p}<0.05)$ at 120 and 150 min intervals and from $60 \mathrm{~min}$ after the start of feeding, respectively.

Plasma glucose concentrations in the RIHS-IB treatment were significantly lower $(\mathrm{p}<0.05)$ than those in the RIAPS-NB control at $-60,30,60,90$, and $150 \mathrm{~min}$ intervals.
Plasma concentrations of $\mathrm{Na}, \mathrm{K}$ and $\mathrm{Cl}$ : The effect of RIHS-IB treatment on plasma concentrations of $\mathrm{Na}, \mathrm{K}$ and $\mathrm{Cl}$ is shown in Table 5. Plasma concentrations of $\mathrm{Na}$ and $\mathrm{Cl}$ in the RIHS-IB treatment increased gradually while they mostly remained unchanged in the RIAPS-NB control during the $2 \mathrm{~h}$ feeding period. Compared with the RIAPS$\mathrm{NB}$ control, plasma concentrations of $\mathrm{Na}$ and $\mathrm{Cl}$ in the RIHS-IB treatment were significantly greater $(\mathrm{p}<0.05)$ from $30 \mathrm{~min}$ and $60 \mathrm{~min}$, respectively, after the commencement of feeding.

Plasma K concentrations in the RIAPS-NB control and the RIHS-IB treatment were similar. There were no significant differences between the RIAPS-NB control and the RIHS-IB treatment in terms of plasma $\mathrm{K}$ concentrations for the duration of the $2 \mathrm{~h}$ feeding period.

Osmolality of plasma and ruminal fluid : Figure 6 shows the effect of RIHS-IB treatment on osmolality of plasma and ruminal fluid. Plasma osmolality in the RIHS-IB treatment increased gradually and reached the level of $317.2 \pm 2.43 \mathrm{mOsmol} / \mathrm{L}$ upon conclusion of the $2 \mathrm{~h}$ feeding period. Meanwhile, plasma osmolality in the RIAPS-NB control increased very slowly and peaked (300.2 $\pm 0.95 \mathrm{mOsmol} / \mathrm{L}$ ) upon conclusion of the $2 \mathrm{~h}$ feeding period. Compared with the RIAPS-NB control, plasma osmolality in the RIHS-IB treatment was significantly higher $(\mathrm{p}<0.05)$ for the duration of the $2 \mathrm{~h}$ feeding period.

Ruminal fluid osmolality in the RIHS-IB treatment increased rapidly and reached the highest level of $465.5 \pm 15.71 \mathrm{mOsmol} / \mathrm{L}$ at $30 \mathrm{~min}$ after the start of feeding and subsequently decreased gradually to the end of the $2 \mathrm{~h}$ feeding period. Meanwhile, ruminal fluid osmolality in the RIAPS-NB control mostly remained unchanged during the $2 \mathrm{~h}$ feeding period. Compared with the RIAPS-NB control, ruminal fluid osmolality in the RIHS-IB treatment was significantly higher $(\mathrm{p}<0.01)$ for the duration of the $2 \mathrm{~h}$ feeding period.

Table 5. The effect of intraruminal infusion of hypertonic solution and insertion of a balloon on hematocrit, plasma concentrations of total protein, glucose, $\mathrm{Na}, \mathrm{K}$, and $\mathrm{Cl}$

\begin{tabular}{|c|c|c|c|c|c|c|c|c|c|c|c|c|c|c|c|c|c|c|}
\hline \multirow{2}{*}{$\begin{array}{l}\text { Time before and } \\
\text { after start of } \\
\text { feeding (min) }\end{array}$} & \multicolumn{3}{|c|}{$\begin{array}{l}\text { Hematocrit } \\
(\%)\end{array}$} & \multicolumn{3}{|c|}{$\begin{array}{l}\text { Plasma total protein } \\
\qquad(\mathrm{g} / \mathrm{dl})\end{array}$} & \multicolumn{3}{|c|}{$\begin{array}{l}\text { Plasma glucose } \\
(\mathrm{mg} / \mathrm{dl})\end{array}$} & \multicolumn{3}{|c|}{$\begin{array}{c}\text { Plasma Na } \\
(\mathrm{mmol} / \mathrm{L})\end{array}$} & \multicolumn{3}{|c|}{$\begin{array}{l}\text { Plasma K } \\
(\mathrm{mmol} / \mathrm{L})\end{array}$} & \multicolumn{3}{|c|}{$\begin{array}{c}\text { Plasma Cl } \\
(\mathrm{mmol} / \mathrm{L})\end{array}$} \\
\hline & $\begin{array}{c}\text { RIAPS- } \\
\text { NB }\end{array}$ & $\begin{array}{l}\text { RIHS- } \\
\text { IB }\end{array}$ & SE & $\begin{array}{c}\text { RIAPS- } \\
\text { NB }\end{array}$ & $\begin{array}{l}\text { RIHS- } \\
\text { IB }\end{array}$ & SE & $\begin{array}{c}\text { RIAPS- } \\
\text { NB }\end{array}$ & $\begin{array}{c}\text { RIHS- } \\
\text { IB }\end{array}$ & SE & $\begin{array}{l}\text { RIAPS- } \\
\text { NB }\end{array}$ & $\begin{array}{l}\text { RIHS- } \\
\text { IB }\end{array}$ & SE & $\begin{array}{l}\text { RIAPS- } \\
\text { NB }\end{array}$ & $\begin{array}{l}\text { RIHS- } \\
\text { IB }\end{array}$ & SE & $\begin{array}{l}\text { RIAPS- } \\
\text { NB }\end{array}$ & $\begin{array}{l}\text { RIHS- } \\
\text { IB }\end{array}$ & SE \\
\hline-60 & 25.9 & 25.8 & 1.37 & 7.1 & 6.8 & 0.29 & $66.0^{\mathrm{a}}$ & $63.8^{\mathrm{b}}$ & 1.92 & 140.8 & 141.3 & 0.86 & 4.6 & 4.7 & 0.23 & 101.0 & 102.2 & 1.05 \\
\hline 0 & 26.1 & 25.8 & 1.44 & 7.1 & 6.9 & 0.29 & 66.2 & 63.7 & 2.49 & 140.5 & 139.0 & 1.69 & 4.7 & 4.9 & 0.16 & 100.3 & 101.3 & 0.83 \\
\hline 15 & 33.8 & 32.8 & 1.64 & 8.4 & 8.3 & 0.29 & 67.5 & 64.3 & 3.79 & 141.3 & 143.3 & 1.27 & 4.8 & 4.8 & 0.15 & $104.8^{b}$ & $107.3^{\mathrm{a}}$ & 1.21 \\
\hline 30 & 34.3 & 32.7 & 1.90 & 8.6 & 8.3 & 0.31 & $66.3^{\mathrm{a}}$ & $62.3^{\mathrm{b}}$ & 2.71 & $140.8^{\mathrm{b}}$ & $144.8^{\mathrm{a}}$ & 1.39 & 4.7 & 4.9 & 0.25 & 105.0 & 107.0 & 1.51 \\
\hline 60 & 34.0 & 31.6 & 1.61 & $8.6^{\mathrm{a}}$ & $8.1^{\mathrm{b}}$ & 0.25 & $65.5^{\mathrm{a}}$ & $61.0^{\mathrm{b}}$ & 3.55 & $141.8^{b}$ & $146.7^{\mathrm{a}}$ & 1.32 & 4.7 & 4.9 & 0.14 & $105.7^{\mathrm{b}}$ & $110.0^{\mathrm{a}}$ & 1.50 \\
\hline 90 & 34.3 & 31.0 & 1.53 & $8.6^{\mathrm{a}}$ & $8.0^{\mathrm{b}}$ & 0.26 & $68.2^{\mathrm{a}}$ & $61.8^{\mathrm{b}}$ & 4.75 & $140.8^{b}$ & $149.8^{\mathrm{a}}$ & 1.93 & 4.8 & 4.9 & 0.24 & $105.7^{\mathrm{b}}$ & $111.8^{\mathrm{a}}$ & 2.10 \\
\hline 120 & $34.5^{\mathrm{a}}$ & $29.6^{\mathrm{b}}$ & 1.95 & $8.7^{\mathrm{a}}$ & $7.7^{\mathrm{b}}$ & 0.19 & 65.7 & 62.2 & 4.11 & $142.2^{\mathrm{b}}$ & $152.5^{\mathrm{a}}$ & 2.21 & 4.8 & 4.7 & 0.27 & $105.3^{b}$ & $114.0^{\mathrm{a}}$ & 1.91 \\
\hline 150 & $29.6^{\mathrm{a}}$ & $25.7^{\mathrm{b}}$ & 1.60 & $7.9^{\mathrm{a}}$ & $7.1^{\mathrm{b}}$ & 0.35 & $68.3^{\mathrm{a}}$ & $64.2^{\mathrm{b}}$ & 4.59 & $140.7^{\mathrm{b}}$ & $151.8^{\mathrm{a}}$ & 1.71 & 4.7 & 4.5 & 0.20 & $102.0^{\mathrm{b}}$ & $112.7^{\mathrm{a}}$ & 1.94 \\
\hline
\end{tabular}

RIAPS-NB = Intraruminal infusion of artificial parotid saliva and non-insertion of a balloon.

RIHS-IB = Intraruminal infusion of hypertonic solution and insertion of a balloon.

Values are means of 6 large-type goats; $\mathrm{SE}=$ Pooled standard error. ${ }^{\mathrm{a}, \mathrm{b}}$ Means in the same row bearing different superscripts differ $(\mathrm{p}<0.05$ ). 

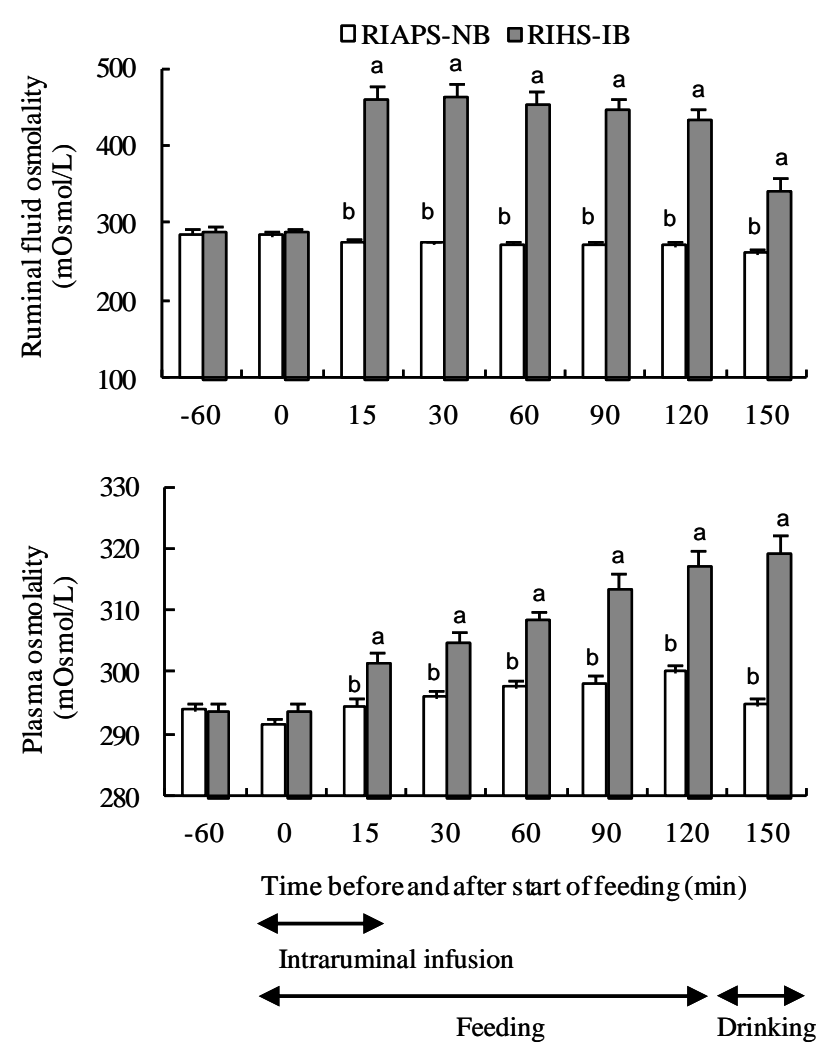

Figure 6. The effect of intraruminal infusion of hypertonic solution and insertion of a balloon (RIHS-IB) on osmolality of plasma and ruminal fluid. Values are means \pm SE of 6 large-type goats. ${ }^{a, b}$ Means with different superscript are significantly different $(\mathrm{p}<0.05)$ from the intraruminal infusion of artificial parotid saliva and non-insertion of a balloon (RIAPS-NB).

Ruminal fluid $\mathrm{pH}$ and concentrations of $\mathrm{Na}, \mathrm{K}$ and $\mathrm{Cl}$ : Table 6 presents the effect of RIHS-IB treatment on ruminal fluid $\mathrm{pH}$ and concentrations of $\mathrm{Na}, \mathrm{K}$ and $\mathrm{Cl}$. Ruminal fluid $\mathrm{pH}$ in both the RIAPS-NB control and the RIHS-IB treatment was slightly higher than compared with prefeeding levels during the $2 \mathrm{~h}$ feeding period. In comparison with the RIAPS-NB control, ruminal fluid $\mathrm{pH}$ in the RIHS-
IB treatment was significantly lower $(\mathrm{p}<0.05)$ at 15,30 , and 150 min intervals.

Ruminal fluid concentrations of $\mathrm{Na}$ and $\mathrm{Cl}$ in the RIHSIB treatment increased rapidly after the start of feeding while they mostly remained unchanged in the RIAPS-NB control during the $2 \mathrm{~h}$ feeding period. Compared with the RIAPS-NB control, ruminal fluid concentrations of $\mathrm{Na}$ and $\mathrm{Cl}$ in the RIHS-IB treatment were significantly higher $(\mathrm{p}<0.05$ and $\mathrm{p}<0.01$, respectively) over the $2 \mathrm{~h}$ feeding period. Ruminal fluid concentrations of $\mathrm{K}$ in both the RIAPS-NB control and the RIHS-IB treatment tended to be reduced gradually as feeding period elapsed. There were no significant differences between the RIAPS-NB control and the RIHS-IB treatment in terms of ruminal fluid concentrations of $\mathrm{K}$ during the $2 \mathrm{~h}$ feeding period.

\section{DISCUSSION}

When feed boluses enter the rumen during dry forage feeding, ruminal fluid osmolality increases and the weight of the feed boluses causes ruminal distension. Volatile fatty acids are produced due to microbial fermentation and ruminal fluid $\mathrm{pH}$ decreases. Due to the large amount of saliva secreted during the initial stages of feeding, circulating plasma volume in the blood decreases and the ruminal absorption of salt content in the consumed feed causes an increase in plasma osmolality which stimulates frequent drinking behavior in the animals. In large-type goats were fed on dry forage twice daily, dry forage intake was markedly suppressed after 30 or 40 min of feeding had elapsed. However, the mechanism responsible for the suppression of dry forage intake after $40 \mathrm{~min}$ of feeding is still unclear.

The results of the present study indicated that in largetype goats were fed on dry forage twice daily, the marked reduction in dry forage intake after $40 \mathrm{~min}$ of feeding period had elapsed was caused by the ruminal distension and an

Table 6. The effect of intraruminal infusion of hypertonic solution and insertion of a balloon on ruminal fluid $\mathrm{pH}$ and concentrations of $\mathrm{Na}, \mathrm{K}$, and $\mathrm{Cl}$

\begin{tabular}{|c|c|c|c|c|c|c|c|c|c|c|c|c|}
\hline \multirow{2}{*}{$\begin{array}{l}\text { Time before and } \\
\text { after start of } \\
\text { feeding (min) }\end{array}$} & \multicolumn{3}{|c|}{ Ruminal fluid $\mathrm{pH}$} & \multicolumn{3}{|c|}{$\begin{array}{l}\text { Ruminal fluid } \mathrm{Na} \\
\qquad(\mathrm{mmol} / \mathrm{L})\end{array}$} & \multicolumn{3}{|c|}{$\begin{array}{l}\text { Ruminal fluid } \mathrm{K} \\
\text { ((mmol/L) }\end{array}$} & \multicolumn{3}{|c|}{$\begin{array}{l}\text { Ruminal fluid } \mathrm{Cl} \\
\quad(\mathrm{mmol} / \mathrm{L})\end{array}$} \\
\hline & RIAPS-NB & RIHS-IB & SE & RIAPS-NB & RIHS-IB & $\mathrm{SE}$ & RIAPS-NB & RIHS-IB & SE & RIAPS-NB & RIHS-IB & SE \\
\hline-60 & 6.94 & 6.88 & 0.13 & 130.7 & 147.5 & 13.74 & $56.3^{\mathrm{b}}$ & $62.9^{\mathrm{a}}$ & 8.74 & 43.4 & 46.8 & 4.79 \\
\hline 0 & 6.96 & 6.90 & 0.12 & 130.9 & 147.7 & 14.87 & 54.3 & 60.5 & 8.80 & 44.7 & 48.5 & 5.65 \\
\hline 15 & $7.20^{\mathrm{a}}$ & $7.00^{\mathrm{b}}$ & 0.12 & $131.7^{\mathrm{b}}$ & $245.3^{\mathrm{a}}$ & 14.27 & 50.3 & 48.7 & 7.38 & $40.6^{\mathrm{b}}$ & $172.3^{\mathrm{a}}$ & 8.18 \\
\hline 30 & $7.25^{\mathrm{a}}$ & $7.05^{\mathrm{b}}$ & 0.11 & $131.3^{\mathrm{b}}$ & $247.9^{\mathrm{a}}$ & 16.23 & 47.6 & 49.6 & 8.02 & $39.6^{\mathrm{b}}$ & $183.7^{\mathrm{a}}$ & 9.10 \\
\hline 60 & 7.25 & 7.11 & 0.11 & $129.6^{\mathrm{b}}$ & $243.5^{\mathrm{a}}$ & 15.34 & 48.7 & 49.4 & 6.81 & $39.6^{\mathrm{b}}$ & $178.6^{\mathrm{a}}$ & 8.75 \\
\hline 90 & 7.25 & 7.10 & 0.11 & $132.4^{\mathrm{b}}$ & $238.0^{\mathrm{a}}$ & 16.62 & 41.7 & 46.0 & 6.09 & $40.6^{\mathrm{b}}$ & $175.2^{\mathrm{a}}$ & 8.62 \\
\hline 120 & 7.25 & 7.10 & 0.10 & $129.8^{\mathrm{b}}$ & $233.5^{\mathrm{a}}$ & 14.71 & 43.5 & 46.5 & 7.36 & $40.6^{\mathrm{b}}$ & $174.4^{\mathrm{a}}$ & 8.32 \\
\hline 150 & $7.26^{\mathrm{a}}$ & $7.10^{\mathrm{b}}$ & 0.10 & $123.9^{b}$ & $201.9^{\mathrm{a}}$ & 13.96 & 40.3 & 38.8 & 6.95 & $39.6^{\mathrm{b}}$ & $143.7^{\mathrm{a}}$ & 7.18 \\
\hline
\end{tabular}

RIAPS-NB = Intraruminal infusion of artificial parotid saliva and non-insertion of a balloon.

RIHS-IB = Intraruminal infusion of hypertonic solution and insertion of a balloon.

Values are means of 6 large-type goats; $\mathrm{SE}=$ Pooled standard error. ${ }^{\mathrm{a}, \mathrm{b}}$ Means in the same row bearing different superscripts differ $(\mathrm{p}<0.05)$. 
increase in plasma osmolality brought about by dry forage feeding (approximately 77.5\%). Because the water content on fresh forage is more than $80 \%$, the increases in ruminal distension during feeding on fresh forage are greater than when dry forage is consumed (Narita et al., 2002). It is therefore thought that fresh forage intake is mainly controlled by increases in ruminal distension rather than increases in plasma osmolality associated with feeding.

Under normal feeding conditions whereby feed boluses entered the rumen, it has been reported that feed intake in ruminants is controlled by a number of factors. These factors include ruminal distension (Campling and Balch, 1961; Mbanya et al., 1987; Anil et al., 1993), volatile fatty acids (Baile and Mayer, 1969; Baile and Forbes, 1974; Bapat and Nangia, 1987; Anil et al., 1993; Mbanya et al., 1993), ruminal fluid osmolality (Baile et al., 1969; Tornouth and Beattie, 1971; Bergen, 1972; Kato et al., 1979; Phillip et al., 1981; Grovum and Bignell, 1989; Grovum, 1995), plasma osmolality (Prasetiyono et al., 2000), and circulating plasma volume (Sunagawa et al., 2001; 2002; 2003; 2005; 2007). However, under normal feeding conditions, it was difficult to clarify which factors are mainly responsible for controlling feed intake because ruminal fluid and blood parameters (ruminal distension, ruminal fluid osmolality, ruminal fluid volatile fatty acids and plasma osmolality), which are thought to suppress feed intake, changed at the same time (Sunagawa et al., 1997; Thang et al., 2010).

Under sham feeding conditions whereby feed boluses are removed before entering the rumen during dry forage feeding, increase in ruminal fluid osmolality, decrease in ruminal fluid $\mathrm{pH}$, and increase in plasma osmolality that occur under normal feeding conditions when feed enters the rumen were not observed (Figure 3 and Table 4; Thang et al., 2010). Thang et al. (2010) found that salivary secretion volume during dry forage feeding, in large-type esophagealfistulated goats were fed dry forage twice daily, was greater in volume than the actual dry forage consumed. Thang et al. (2011b) also indicated that the marked decrease in dry forage intake in the second hour of the $2 \mathrm{~h}$ feeding period is related to ruminal distension caused by the feed consumed and the copious amount of saliva secreted during dry forage feeding in large-type esophageal-fistulated goats were fed dry forage twice daily. Furthermore, Thang et al. (2011a) has reported that when ruminal fluid osmolality increases during dry forage feeding, plasma osmolality must also increase and drinking behavior is consequently observed. Thang et al. (2011a) has found that the marked decreases in dry forage intake after $40 \mathrm{~min}$ of feeding are partly caused by increases in plasma osmolality and subsequent thirst sensations produced by dry forage feeding. Eating rates and cumulative dry forage intake under sham feeding conditions increased significantly compared to those under normal feeding conditions (Figure 1). These facts indicate that some factors are additively working to markedly suppress feed intake $40 \mathrm{~min}$ after the start of feeding.

In the SFC and RIAPS-NB controls, saliva lost via the esophageal fistula was replenished by an intraruminal infusion of artificial parotid saliva. An intraruminal infusion of hypertonic solution and insertion of a balloon in the RIHS-IB treatment were carried out in order to reproduce the effects of changing salt content and ruminal distension due to feed entering the rumen. The volume of artificial parotid saliva that was replenished in the rumen was approximately equal to the total volume of secreted saliva recorded during the $2 \mathrm{~h}$ feeding period under sham feeding conditions (Thang et al., 2010). The weight of water that was infused into the balloon in the rumen was equivalent to the weight of feed boluses removed via an esophageal fistula during the $2 \mathrm{~h}$ feeding period (Thang et al., 2010). After the intraruminal infusion of a hypertonic solution mixed with the rumen contents, the highest level of ruminal fluid osmolality in the RIHS-IB treatment was recorded to be $465.5 \pm 15.71 \mathrm{mOsmol} / \mathrm{L}$. This value was still lower compared with the highest level of ruminal fluid osmolality $(536.8 \pm 19.85 \mathrm{mOsmol} / \mathrm{L})$ in the NFC treatment of experiment 1. From these results, it is thought that the effects of ruminal distension and increased plasma osmolality induced thirst on dry forage intake reproduced in the RIHS-IB treatment were mostly the same as those in the normal feeding conditions.

Cumulative dry forage intake in NFC treatment decreased to $43.8 \%$ of the SFC control. On the other hand, cumulative dry forage intake in the RIHS-IB treatment reduced to $34.0 \%$ of the RIAPS-NB control. From many reports (Campling and Balch, 1961; Baile and Mayer, 1969; Baile and Forbes, 1974; Kato et al., 1979; Anil et al., 1993; Prasetiyono et al., 2000; Sunagawa et al., 2001; 2002; 2003; 2005 ; 2007), it is thought that under normal feeding conditions such as the NFC treatment, multiple physiological factors are involved in the suppression of dry forage intake. However, in the RIHS-IB treatment, there were only two factors (ruminal distension and increased plasma osmolality) involved in the suppression of dry forage intake under sham feeding conditions. Consequently, the combined effect of ruminal distension and increased plasma osmolality induced thirst accounted for $77.5 \%$ of the suppression of dry forage intake $40 \mathrm{~min}$ after the start of feeding while other factors were responsible for $22.5 \%$ of this suppression of dry forage intake. It has been reported that peptides such as vasopressin (Meyer et al., 1989), angiotensin II (Sunagawa et al., 2001), corticotropinreleasing factor (Sunagawa et al., 2000), urocortin (Sunagawa et al., 2000), cholecystokinin (Grovum, 1981), and leptin (Henry et al., 1999) suppress dry forage intake in sheep. It is therefore thought that the $22.5 \%$ suppression of dry forage intake in large-type goats can be partly attributed 
to these peptides. It can be concluded that ruminal distension and increased plasma osmolality induced thirst are the main factors in the suppression of dry forage intake in large-type goats.

The present study advances knowledge of the control of dry forage intake in domestic ruminants. Such information is an essential requirement in the development of methods to improve management, welfare and performance.

\section{ACKNOWLEDGEMENTS}

We thank Miss Yui Naito, Miss Tomoko Sasaki, Mr. Yutaro Tominaga and Miss Yuki Nishida for their helpful assistance in experiments and recording the data. We also thank Mr. Glenn McIlvride for his English proof-reading on this manuscript.

\section{REFERENCES}

Anil, M. H., J. N. Mbanya, H. W. Symonds and J. M. Forbes. 1993. Responses in the voluntary intake of hay or silage by lactating cows to intraruminal infusions of sodium acetate, sodium propionate or rumen distension. Br. J. Nutr. 69:699-712.

AOAC. 1990. Official methods of analysis. 15th Ed. Association of Official Analytical Chemists, Arlington, Virginia.

Baile, C. A. and J. M. Forbes. 1974. Control of feed intake and regulation of energy balance in ruminants. Physiol. Rev. 54:160-214.

Baile, C. A. and J. Mayer. 1969. Depression of feed intake of goats by metabolites injected during meals. Am. J. Physiol. 217:1830-1836.

Baile, C. A., J. Mayer and C. L. McLaughlin. 1969. Feeding behavior of goats: ruminal distension, ingesta dilution and acetate concentration. Am. J. Physiol. 217:397-402.

Bapat, S. T. and O. P. Nangia. 1987. Effect of intraruminal infusion of volatile fatty acids on voluntary feed intake and rumen motility in buffaloes. Buffalo J. 2:127-139.

Bergen, W. G. 1972. Rumen osmolality as a factor in feed intake control of sheep. J. Anim. Sci. 34:1054-1060.

Campling, R. C. and C. C. Balch. 1961. Factors affecting the voluntary feed intake of the cow. 1. Preliminary observations on the effect, on the voluntary intake of hay, of changes in the amount of the reticulo-ruminal contents. Br. J. Nutr. 15:523530.

Grovum, W. L. 1981. Factors affecting the voluntary intake of food by sheep. 3. The effect of intravenous infusions of gastrin, cholecystokinin and secretin on motility of the reticulo-rumen and intake. Br. J. Nutr. 45:183-201.

Grovum, W. L. 1995. Mechanisms explaining the effects of short chain fatty acids on feed intake in ruminants-osmotic pressure, insulin and glucagons. In: Ruminant physiology: Digestion, Metabolism, Growth and Reproduction. Proceedings of the Eight International Symposium on Ruminant Physiology (Ed. W. V. Engelhardt, S. Leonhard-Marek, G. Breves and D. Giesecke). Ferdinant Enke Verlag, Stuttgart, Germany. pp. 173-197.

Grovum, W. L. and W. W. Bignell. 1989. Results refuting volatile fatty acids per se as signals of satiety in ruminants. Proc. Nutr. Soc. 48:3A.

Guyton, A. C. and J. E. Hall. 1996. Central nervous system centers for thirst. In: Textbook of Medical Physiology. W. B. Saunders Company, Philadelphia, Pennsylvania. p. 361.

Henry, B. A., J. W. Goding, W. S. Alexander, A. J. Tilbrook, B. J. Canny, F. Dunshea, A. Rao, A. Mansell and I. J. Clarke. 1999. Central administration of leptin to ovariectomised ewes inhibits food intake without affecting the secretion of hormones from pituitary gland: evidence for a dissociation of effects on appetite and neuroendocrine function. Endocrinology 140:1175-1182.

Kato, S., Y. Sasaki and T. Tsuda. 1979. Food intake and rumen osmolality in the sheep. Ann. Rech. Vet. 10:229-230.

Mbanya, J. N., M. H. Anil and J. M. Forbes. 1987. Rumen distension and depression of voluntary hay intake of the lactating cow. Proceedings of the 38th Annual Meeting of the European Association of Animal Production, Lisbon, p. 424.

Mbanya, J. N., M. H. Anil and J. M. Forbes. 1993. The voluntary intake of hay and silage by lactating cows in response to ruminal infusion of acetate or propionate, or both, with or without distension of the rumen by a balloon. Br. J. Nutr. 69:713-720.

McKinley, M. J. and A. K. Johnson. 2004. The physiological regulation of thirst and fluid intake. News Physiol. Sci. 19:1-6.

Meyer, A. H., W. Langhans and E. Scharrer. 1989. Vasopressin reduces food intake in goats. Q. J. Exp. Physiol. Cogn. Med. Sci. 74:465-473.

Narita, H., S. Sato and K. Sugawara. 2002. Herbage intake and water balance of sheep fed on fresh grass and hay. Grassland Sci. 48:126-129.

Phillip, L. E., J. G. Buchanan-Smith and W. L. Grovum. 1981. Food intake and ruminal osmolality in sheep: Differentiation of the effect of osmolality from that of the products of maize silage fermentation. J. Agric. Sci. 96:439-445.

Prasetiyono, B. W. H. E., K. Sunagawa, A. Shinjo and S. Shiroma. 2000. Physiological relationship between thirst level and feed intake in goats fed on alfalfa hay cubes. Asian-Aust. J. Anim. Sci. 13:1536-1541.

SAS. 1990. SAS/STAT user's guide: Volume 2, Version 6. 4th Ed. SAS Institute Inc., SAS Campus Drive, Cary, NC 27513.

Sunagawa, K., T. Hashimoto, M. Izuno, N. Hashizume. M. Okano, I. Nagamine, T. Hirata and A. Shinjo. 2008. An intravenous replenishment of salivary components decreases water intake and increases feed intake in freely drinking large-type goats fed dry forage. Can. J. Anim. Sci. 88:237-245.

Sunagawa, K., Y. Nakatsu, Y. Nishikubo, T. Ooshiro, K. Naitou and I. Nagamine. 2002. Effects of intraruminal saliva flow on feed intake in goats fed on alfalfa hay cubes. Asian-Aust. J. Anim. Sci. 15:1738-1746.

Sunagawa, K., Y. Nakatsu, Y. Nishikubo, T. Ooshiro, K. Naitou and I. Nagamine. 2003. Effect of parotid saliva secretion on dry forage intake in goats. Asian-Aust. J. Anim. Sci. 16:11181125.

Sunagawa, K., T. Ooshiro, N. Nakamura, I. Nagamine, S. Shiroma and A. Shinjo. 2005. Controlling factors of feed intake and salivary secretion in goats fed on dry forage. Asian-Aust. J. Anim. Sci. 18:1414-1420.

Sunagawa, K., T. Ooshiro, N. Nakamura, Y. Ishii, I. Nagamine and 
A. Shinjo. 2007. Physiological factors depressing feed intake and saliva secretion on goats fed on dry forage. Asian-Aust. J. Anim. Sci. 20:60-69.

Sunagawa, K., M. Sakurada, H. Takahashi, F. Hongo, A. Shinjo and S. Shiroma. 1997. The ruminal concentrations of volatile fatty acids and digestibility of the feed fractions in goats exposed to hot environment. Ami. Sci. Technol. (Jpn). 68:156162.

Sunagawa, K., R. S. Weisinger, M. J. McKinley, B. S. Purcell, C. Thomson and P. L. Burns. 2000. The role of corticotropinreleasing factor and urocortin in brain mechanisms controlling feed intake of sheep. Asian-Aust. J. Anim. Sci. 13:1529-1535.

Sunagawa, K., R. S. Weisinger, M. J. McKinley, B. S. Purcell, C. Thomson and P. L. Burns. 2001. The role of angiotensin II in the central regulation of feed intake in sheep. Can. J. Anim. Sci. $81: 215-221$.
Ternouth, J. H. and A. W. Beattie. 1971. Studies of the food intake of sheep at a single meal. Br. J. Nutr. 25:153-165.

Thang, T. V., K. Sunagawa, I. Nagamine and S. Kato. 2010. Deprivation of esophageal boluses and dry forage intake in large-type goats. Asian-Aust. J. Anim. Sci. 23:1174-1183.

Thang, T. V., K. Sunagawa, I. Nagamine and G. Ogura. 2011a. Plasma osmolality controls dry forage intake in large-type goats. Asian-Aust. J. Anim. Sci. 24:1069-1085.

Thang, T. V., K. Sunagawa, I. Nagamine and G. Ogura. $2011 \mathrm{~b}$. Salivary secretion volume related ruminal distension and suppression of dry forage intake in large-type goats. AsianAust. J. Anim. Sci. 24:1100-1111.

Van Soest, P. J., J. B. Robertson and B. A. Lewis. 1991. Methods for dietary fiber, neutral detergent fiber, and nonstarch polysaccharides in relation to animal nutrition. J. Dairy Sci. 74:3583-3597. 